\title{
QUALITY OF PRECIPITATION ANNEALING OF HEAT-RESISTANT CAST STEEL USING A TAGUCHI ANALYSIS
}

\author{
OCENA KVALITETE IZLOČEVALNEGA ŽARJENJA TERMIČNO \\ OBSTOJNE JEKLENE LITINE Z UPORABO TAGUCHIJEVE \\ ANALIZE
}

\author{
Martin Folta ${ }^{1}$, Alen Delić ${ }^{2}$ \\ 1ŠKODA AUTO University, Department of Production, Logistics and Quality Management, Na Karmeli 1457, \\ Mladá Boleslav, Czech Republic \\ ${ }^{2}$ TTU energetik d.o.o. Tuzla, 18. Hrvatske brigade br. 25, Tuzla, Bosnia and Herzegovina
}

Prejem rokopisa - received: 2020-05-08; sprejem za objavo - accepted for publication: 2020-10-26

doi:10.17222/mit.2020.074

\begin{abstract}
In this study, the effects of temperature and time on the hardness of heat-resistant cast steel HK30 Nb obtained with centrifugal casting were analysed using the Taguchi method. On the basis of the analysis of the obtained results, we reached reliable conclusions on the improvement of the exploitation properties. The tests showed that precipitation annealing of a $\mathrm{HK} 30 \mathrm{Nb}$ casting can improve the exploitation properties at high temperatures. The defined temperature and holding time comply with the results of the mathematical analysis of the achieved properties, and the presumed research theory from this study can hence be confirmed. The studies showed that the mechanical properties improved during the precipitation-annealing process. During this process, significant transformations of the carbide phase occur in the microstructure, thereby changing its morphology, distribution, size and composition, which was confirmed by testing the microstructure with a scanning electron microscope.
\end{abstract}

Keywords: Taguchi analysis, designed experiment, heat-resistant cast steel, precipitation annealing, microstructure, product quality

V pričujoči študiji avtorja s pomočjo Taguchijeve metode analizirata vpliv temperature in časa izločevalnega žarjenja na trdoto termično obstojne jeklene litine HK30 Nb izdelane s centrifugalnim litjem. Na osnovi dobljenih rezultatov analize sta prišla do zanesljivih zaključkov, ki omogočajo izboljšanje uporabnih lastnosti izbrane litine. Preizkusi so pokazali, da izločevalno žarjenje HK30 Nb litine lahko izboljša uporabne lastnosti litine pri povišanih temperaturah. Definirane temperature in časi zadrževanja se ujemajo z rezultati doseženih lastnosti na osnovi matematične analize. Na osnovi predpostavljene raziskovalne teorije v tej študiji sta avtorja potrdila praktično dosežene lastnosti. Študija je pokazala, da se mehanske lastnosti izbrane litine izboljšajo s postopkom izločevalnega žarjenja. Med postopkom precipitacijskega žarjenja je prišlo v mikrostrukturi do pomembne pretvorbe karbidne faze, to je spremembe njene morfologije, velikostne porazdelitve in sestave, kar je bilo ugotovljeno z metalografskimi preiskavami na vrstičnem elektronskem mikroskopu.

Ključne besede: Taguchijeva analiza, oblikovanje eksperimenta, termično obstojna jeklena litina, izločevalno žarjenje, mikrostruktura, kakovost izdelka

\section{INTRODUCTION}

\subsection{Application of the designed experiment in research}

The Taguchi method (TM) of experimental design, based on the application of Taguchi's experimental designs, is a well-known, unique and powerful technique developed to improve the quality of products and processes. It represents a simple and efficient method of experimental design. The application of the method is not limited to specific problems, and it is mainly used for experimental analyses and for the optimisation of products and processes. Generally speaking, the TM application procedure consists of several steps. The classic experimental design is sometimes too complex and it takes a long time. When the number of factors increases, it is necessary to carry out numerous experimental tests. On the other hand, the TM is based on the application of special, partial factorial designs obtained from orthogo-

*Corresponding author's e-mail:

martin.folta@savs.cz (Martin Folta) nal designs, which cover the entire experimental space of interest with a minimum number of experiments in comparison with the classic experimental design, and particularly in comparison with full factorial designs. A lower number of experiments implies a reduction in the time and expenses. If a full factorial design has several factors and variance levels for each factor, the total number of experiments $(\mathrm{N})$ can be obtained using the following Equation (1):

$$
N=L^{\mathrm{k}}
$$

where $L$ is the number of variance levels and $\mathrm{k}$ is the number of factors. For example, for the experiment with 4 factors and 3 levels, the application of the full factorial design requires $34=81$ experiments. On the other hand, using Taguchi's experimental design, with the standard 4 orthogonal sequence $L 9$ (3), the number of required experiments is reduced to only $9^{1-2}$.

Taguchi wanted to find an effective manner of their statistical presentation, and he defined three situations: 
- smaller is better - when the target value of the response is around zero (e.g., emission of harmful gases, energy consumption),

- larger is better - when the goal is to reach the maximum target value of the response (e.g., product yield, conversion of reactants into products),

- nominal is best - when the goal is to reach the mean target value of the response (e.g., particle size, product properties).

The main idea behind the Taguchi methodology is to apply the experimental-design technique with a view to defining the levels of controllable factors, which make the process robust and with the presence of uncontrollable factors (noises). Such noises have a significant effect on the response of the process, i.e., on the product quality, and either it is not possible to control them or it is economically too demanding to maintain them at a certain constant value. The noises are the main reason for the occurrence of variation in the system. Using the Taguchi method, the product quality is defined as the deviation of a certain response from the desired value. Experiments are carried out in such a manner as to establish the variability range occurring as a result of variance for controllable factors and uncontrollable factors (noises). Taguchi recommends using the orthogonal array of the experimental design, the full experimental design, one for each of the two groups of factors (controllable variables and noises). Unlike the traditional Fisher approach, which implies that the error is distributed randomly within the design, the Taguchi design enables an analysis of the effect of the error (noises) on the response., ${ }^{2,12-14}$

The levels of the process parameters form the inner array, while the full noise design makes the outer array. The outer array consists of four rows, $n=22$ (2-level, 2 -factor full design), while the inner array has eight columns, $m=23$ (2-level, 3-factor full design). Such a design, as developed by Taguchi, is depicted as a classic design of controllable factors, which makes the inner array, with the addition of the outer noise array in each corner of the inner array.

In such a manner, there are $22 \times 23=32$ defined experimental conditions, and the response of the process is observed for each set of conditions (yij), while the signal-to-noise ratio $(S / N)$ is calculated for each point of the inner array. In such a case, the combination of controllable factors corresponding to the highest $S / N$ value represents the worst production conditions within the boundaries of the tested effects of noises.

In the experiment theory, which covers experimental planning with the creation and analysis of experimental designs, for operational implementation of the designed plan arrays and mathematical processing of experimental results, two basic statistical methodologies are used dispersion and regression analysis. ${ }^{3-6,8,12-15}$

Correlation-analysis methods enable statistical evaluations of the quantitative measures of the regression dependence of variables. The simple correlation coefficient is taken as the quantitative measure of linear depend- ence, while the quantitative measure of linear dependence of one dependent variable on several independent variables is known as the multiple-correlation coefficient. When introducing a new variable or omitting one of the previously mentioned independent variables in a multiple-regression model, the multiple-correlation coefficient can be lower, higher, or it can remain unchanged. Based on that, we estimate the effect of the introduced or omitted independent variable on the total variability of the dependent variable. Therefore, by removing the linear dependence caused by the effect of the other independent variables in the linear regression model, we can obtain the quantitative measure of dependence known as the partial correlation coefficient. ${ }^{4,7}$

\subsection{Precipitation annealing}

The obstacles to the movement of dislocations are spatial or three-dimensional, such as the separated phases of carbides, nitrides or intermetallic seams. These phases occur when the melting boundaries of foreign atoms (atoms of alloyants) in the crystal grid of the basic metal are exceeded.

The effect of these phases is reflected in their distribution and type (coherent, semi-coherent, incoherent), size and distance. When coming across precipitates, dislocations can cut them off or pass by them, which again requires a certain amount of energy in the case of an external load, causing an increase in the yield stress $\Delta R e_{4}$ which is calculated as per Equation (2):

$$
\Delta \operatorname{Re}_{4}=\frac{G \cdot b}{2 \pi L} \cdot \ln \frac{L}{2 b}
$$

where:

$G$ - the shear modulus;

$b-$ the Burgers vector;

$L$ - the distance between particles.

For precipitation hardening, it is preferable to have as many as possible of equally scattered small hard particles (precipitates) whose dislocations will have to pass rather than 'cut' them. ${ }^{9-11}$

The basic mechanisms taking place in the microstructure in a precipitation-annealing process are:

- Transformation of coarse primary carbides M7C3, separated in the form of a grid over the dendritic austenitic boundaries of the grains,

- Separation of fine secondary carbides M23C6 and transformation of coarse primary carbides MC. ${ }^{10}$

\section{EXPERIMENTAL PART}

The experimental part of this research is presented by the application of the designed experiment. The precipitation annealing was carried out on cut-off segments of castings, at three selected temperatures $(750,850$ and 950) ${ }^{\circ} \mathrm{C}$, with holding times at each temperature of $(60$, 120 and 180) min, and subsequent quick cooling 
(quenching) in water. The studies included the annealing temperatures and times, at which the processes taking place in the microstructure resulted in a change in the structure and properties. The temperature of $750{ }^{\circ} \mathrm{C}$ was the operating temperature during the use of this material, while the other two temperatures were selected in order to establish if there was any possibility of increasing the operating temperature of the motor, an important objective of the conducted studies.

In this study, the Taguchi method was used to determine the effect of the heat-treatment parameters on the mechanical properties, i.e., on the hardness. The most suitable sequence was $L_{9}\left(3^{2}\right)$ (the standard orthogonal sequence), which requires 9 experimental tests in the experimental design for three levels of testing, where the two factors, the temperature and time, were taken into consideration. Eventually, the values of the two parameters, temperature and time, were selected and the experimental conditions are given in Table $\mathbf{1}$.

Table 1: Parameters and levels of precipitation annealing

\begin{tabular}{|c|c|c|c|c|}
\hline Process factor & Unit & Level 1 & Level 2 & Level 3 \\
\hline Temperature & ${ }^{\circ} \mathrm{C}$ & 750 & 850 & 950 \\
\hline Time & Minute & 60 & 120 & 180 \\
\hline
\end{tabular}

The relevant categories of the $S / N$ (signal to noise) ratio were selected depending on the nature of the response. For a more detailed test of the importance of the effect of the main factors and their interactions on the response, it is possible to use the analysis of variance (ANOVA). However, instead of the ANOVA analysis, Taguchi recommended the analysis of the mean values and the $S / N$ ratio using 2-D graphics of the response.

We examined the importance of controllable factors using the $S / N$ ratio approach. It is usually required to have a low value of hardness after precipitation annealing. For that reason, "smaller is better" for the $S / N$ ratio was used for the above-mentioned parameters. Irrespective of the category of performance characteristics, a high value of the $S / N$ ratio corresponds to better perfor-

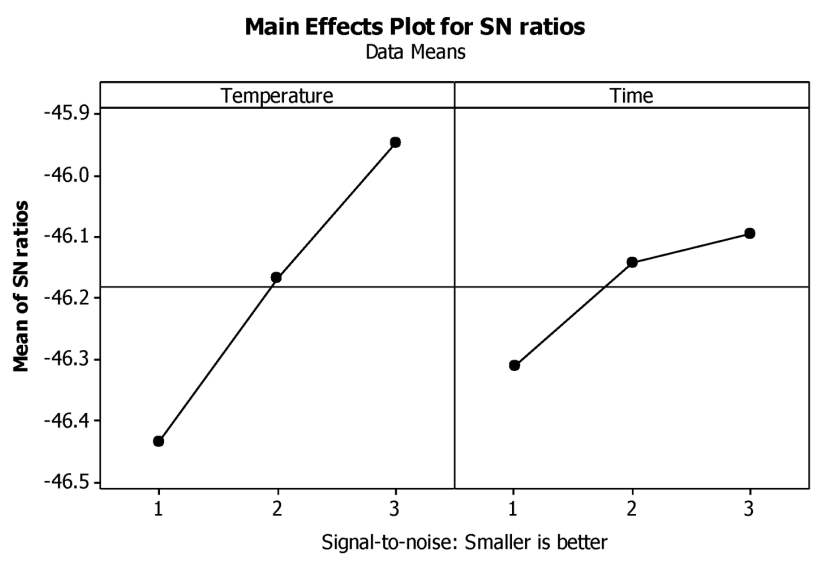

Figure 1: Effects of the main factors on the $S / N$ ratio for the hardness mances. Therefore, the best level of process parameters is the level with the highest $S / N$ ratio.

With a view to determining the effect of the values of the precipitation-annealing factors on the target function, an analysis of the $S / N$ value was carried out using the analysis of the mean values of the hardness results.

Within the analysis, we created the main effects plots, which show the values of the target function at each factor level. The main effect of a factor can be defined as the average change of the target function when the factor changes from a lower to a higher level. The slope of the line on the plot shows that an increase in the value of a factor results in an increase in the value of the target function. The size of the slope determines the strength of the effect of the factor on the value of the target function.

The analysis of the effect of each control factor on the hardness was derived from Table 2.

Table 2: Control factors and mean hardness results

\begin{tabular}{|c|c|c|}
\hline Temperature $-{ }^{\circ} \mathrm{C}$ & Time - min & Hardness - HB \\
\hline 750 & 60 & 214.00 \\
\hline 750 & 120 & 208.33 \\
\hline 750 & 180 & 207.00 \\
\hline 850 & 60 & 206.00 \\
\hline 850 & 120 & 201.17 \\
\hline 850 & $\mathbf{1 8 0}$ & 203.00 \\
\hline 950 & 60 & 200.50 \\
\hline 950 & 120 & 199.00 \\
\hline 950 & $\mathbf{1 8 0}$ & $\mathbf{1 9 5 . 3 3}$ \\
\hline
\end{tabular}

The $S / N$ ratio for the hardness is shown in Table 3 . The $S / N$ ratio is shown for each level of control factors, as well as its change when the settings of each control factor are changed from one level to another.

Table 3: Results of the $S / N$ ratio ("smaller is better") for the hardness

\begin{tabular}{|c|c|c|}
\hline Level & Temperature & Time \\
\hline 1 & -46.43 & -46.31 \\
\hline 2 & -46.17 & -46.14 \\
\hline 3 & -45.94 & -46.09 \\
\hline Difference min.-max. & 0.49 & 0.21 \\
\hline Ranking & 1 & 2 \\
\hline
\end{tabular}

The effect of each control factor on the hardness can be presented more clearly with a relevant plot, see Figure 1.

Figure 1 shows the level, which needs to be selected for the precipitation-annealing parameters (the level with the highest point on the plot), and the relative effect that each parameter has on the $S / N$ ratio (the slope of the line). As presented with the plots showing the effect of the $S / N$ ratio, the slope of the line between different levels can clearly show the power of the effect of each control factor. It is particularly clear that the temperature has a strong effect on the hardness. The time has a weaker effect, which is shown by the small slope of the line. 


\section{FOLTA, A. DELIĆ: QUALITY OF PRECIPITATION ANNEALING OF HEAT-RESISTANT CAST STEEL ...}

Table 4 presents the results of the ANOVA for the hardness. In this case, the precipitation-annealing temperature is also a more significant factor than the time for the hardness. The best precipitation-annealing parameters for the hardness are $950{ }^{\circ} \mathrm{C}$ and $180 \mathrm{~min}$.

Table 4: Hardness-variance analysis

\begin{tabular}{|c|c|c|c|c|c|}
\hline Factor & $\begin{array}{c}\text { Degree of } \\
\text { freedom }\end{array}$ & $\begin{array}{c}\text { Sum of } \\
\text { square }\end{array}$ & $\begin{array}{c}\text { Mean } \\
\text { square } \\
\text { (MS) }\end{array}$ & $F$ ratio & P value \\
\hline $\begin{array}{c}\text { Tempera- } \\
\text { ture }\end{array}$ & 2 & 0.36026 & 0.36026 & 36.92 & 0.003 \\
\hline Time & 2 & 0.07639 & 0.07639 & 7.83 & 0.041 \\
\hline Error & 4 & 0.01952 & 0.01952 & & \\
\hline Total & 8 & 0.45617 & & & \\
\hline
\end{tabular}

A comparison between the Taguchi prediction and the actual (experimental) results was made.

The best hardness results were obtained for the temperature of $950{ }^{\circ} \mathrm{C}$ and the time of 180 minutes. There was little difference between the Taguchi prediction and the actual $S / N$ ratio results, and there was little variation in the hardness values (195.33 and 196.24), resulting in a difference of $0.91 \mathrm{HB}$.

\section{Exponential model:}

The array design that meets the stated requirements for the two-factor design case is presented in Table 5.

The coded parameter values are +1 for the maximum value and -1 for the minimum value of the physical parameter. When there is an intermediate level, the coded value is zero. In this case, the coding is done using the following equations:

\section{Factor coding:}

$$
\begin{gathered}
X_{i}=\frac{x_{i}-x_{0 i}}{\frac{x_{i \max }-x_{i \min }}{2}}=\frac{x_{i}-x_{0 i}}{\Delta x_{i}} \\
x_{0 i}=\frac{x_{\text {max }}-x_{i \min }}{2}
\end{gathered}
$$

$X_{i}$ - the coded parameter value (independent variable),

$i$ - the number of independent variables $(\mathrm{I}=1,2,3, \ldots)$,

$\chi_{i}$ - the physical-parameter value at the upper or lower levels,

$\chi_{0 i}$ - the physical-parameter value at the design centre and
$\Delta \chi_{i}$ - the interval for variance - the difference between the physical-parameter values from the centre to the maximum and minimum values, respectively.

In the factorial design for the two factors of variation, five experimental points were obtained, with the fifth experimental point representing the experiment at the design centre.

Substitute for $T: x_{i}=\ln T, x_{0 i}+\Delta x_{i}=\ln T_{\max }, x_{0 i}-\Delta x_{i}$ $=\ln T_{\min }, 2 \Delta x_{i}=\ln T_{\max }-\ln T_{\min }$

We get:

$$
X_{1}=1+2 \frac{\ln T-\ln T_{\max }}{\ln T_{\max }-\ln T_{\min }}
$$

Substitute for $t$ :

$x_{i}=\ln t, x_{0 i}+\Delta x_{i}=\ln t_{\max }, x_{0 i}-\Delta x_{i}=\ln t_{\min }, 2 \Delta x_{i}=\ln$ $t_{\max }-\ln t_{\min }$

We get:

$$
\begin{gathered}
X_{2}=1+2 \frac{\ln t-\ln t_{\max }}{\ln t_{\max }-\ln t_{\min }} \\
X_{1}=8.475 \ln T-57.104 \\
X_{2}=1.821 \ln (t)-8.4513 \\
Y=b_{0}+b_{1} X_{1}+b_{2} X_{2}+b_{12} X_{1} X_{2} \\
Y=5.31567+0.0308 X_{1}+0.01485 X_{2}+ \\
+0.001783 X_{1} X_{2}
\end{gathered}
$$

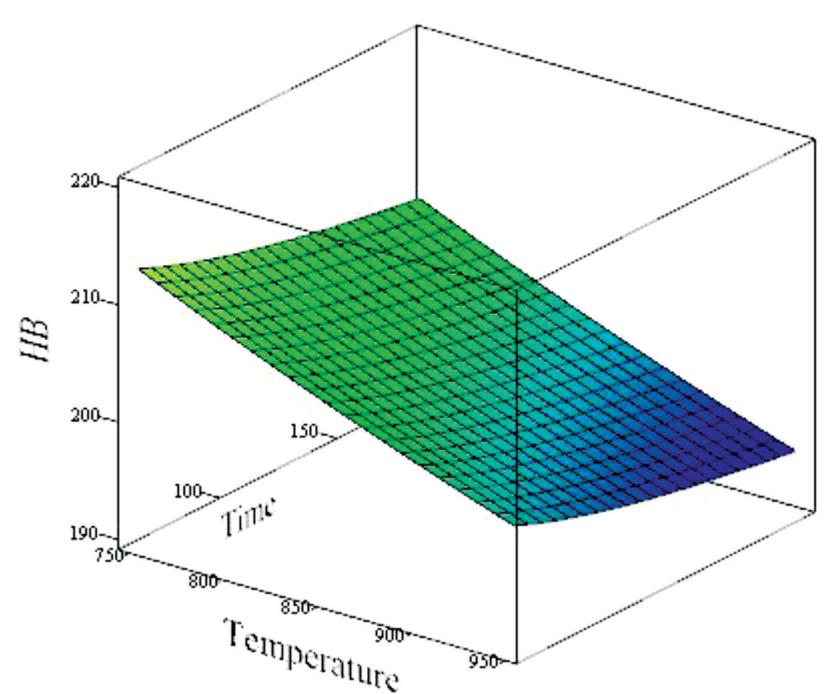

Figure 2: Effects of the interaction of the temperature and time on the hardness $(\mathrm{HB})$

Table 5: Orthogonal array design

\begin{tabular}{|c|c|c|c|c|c|c|}
\hline \multirow{2}{*}{ Exp. point No. } & \multicolumn{3}{|c|}{ Array of coded values } & & Linear model & Exponential model \\
\cline { 2 - 7 } & $X_{0}$ & $X_{1}$ & $X_{2}$ & $X_{12}$ & HB & HB \\
\hline 1 & 1 & -1 & -1 & 1 & 214 & 5.365976 \\
\hline 2 & 1 & -1 & 1 & -1 & 207 & 5.332719 \\
\hline 3 & 1 & 1 & -1 & -1 & 200.5 & 5.300814 \\
\hline 4 & 1 & 1 & 1 & 1 & 195.33 & 5.27469 \\
\hline 5 & 1 & 0 & 0 & 0 & 201.17 & 5.30415 \\
\hline
\end{tabular}




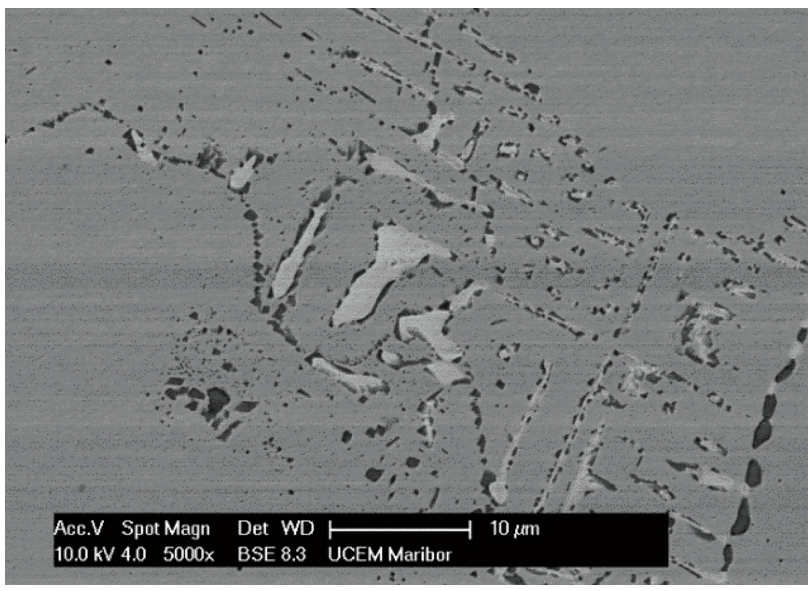

Figure 3: Microstructure of the representative sample T6 $\left(850{ }^{\circ} \mathrm{C} /\right.$ $180 \mathrm{~min}$ ) after precipitation annealing at a higher magnification of $5000 \times$

After decoding, we get:

$$
\ln (T)=5.31567-0.308[8.475 \ln (T)-57.104]
$$

Model:

$$
H B(T, t)=\frac{1339.397}{T^{0.26103} t^{0.027027}}
$$

In order to analyse the effect of the interaction of the factors of precipitation annealing on the hardness, a 3-D surface diagram was created by varying two factors simultaneously, as shown in Figure 2.

The value of the multiple-regression coefficient ranges from $0 \leq R=1$. The closer the value of the multiple-regression coefficient to 1 , the greater is the interde- pendence between the independent and dependent variables. The coefficient of determination $R^{2}$ ( $R$ square) determines the quality and reliability of the mathematical model. For the analysed process, the coefficient of determination $R^{2}=0.965$, which means that $96.5 \%$ of the variability is attributed to the effect of independent variable $\mathrm{x}$ on the hardness.

\section{RESULTS AND DISCUSSION}

The microstructure in the precipitation-annealed state was examined with a QUANTA Scanning Electron Microscope FEI SIRION 400NC, equipped with an EDS (energy-dispersive X-ray spectroscopy) system by INCA, Oxford Instruments, at the University Centre for Electron Microscopy, Institute for Materials Technology, University of Maribor.

The microstructure examined on SEM images at a $5000 \times$ magnification is shown in Figure 3. The marked micro-zone in the microstructure was examined using a quantitative EDS analysis.

Having examined the carbide phase with the scanning electron microscope (SEM), it was observed that in the microstructure of the sample precipitation-annealed at $850^{\circ} \mathrm{C}$ for 180 minutes, large amounts of $\mathrm{Nb}$ and $\mathrm{C}$ on a single carbide were confirmed with the quantitative EDS analysis; hence, it can be claimed that it is $\mathrm{NbC}$ carbide (Figure 4, spectrum 1/b), Table 6).
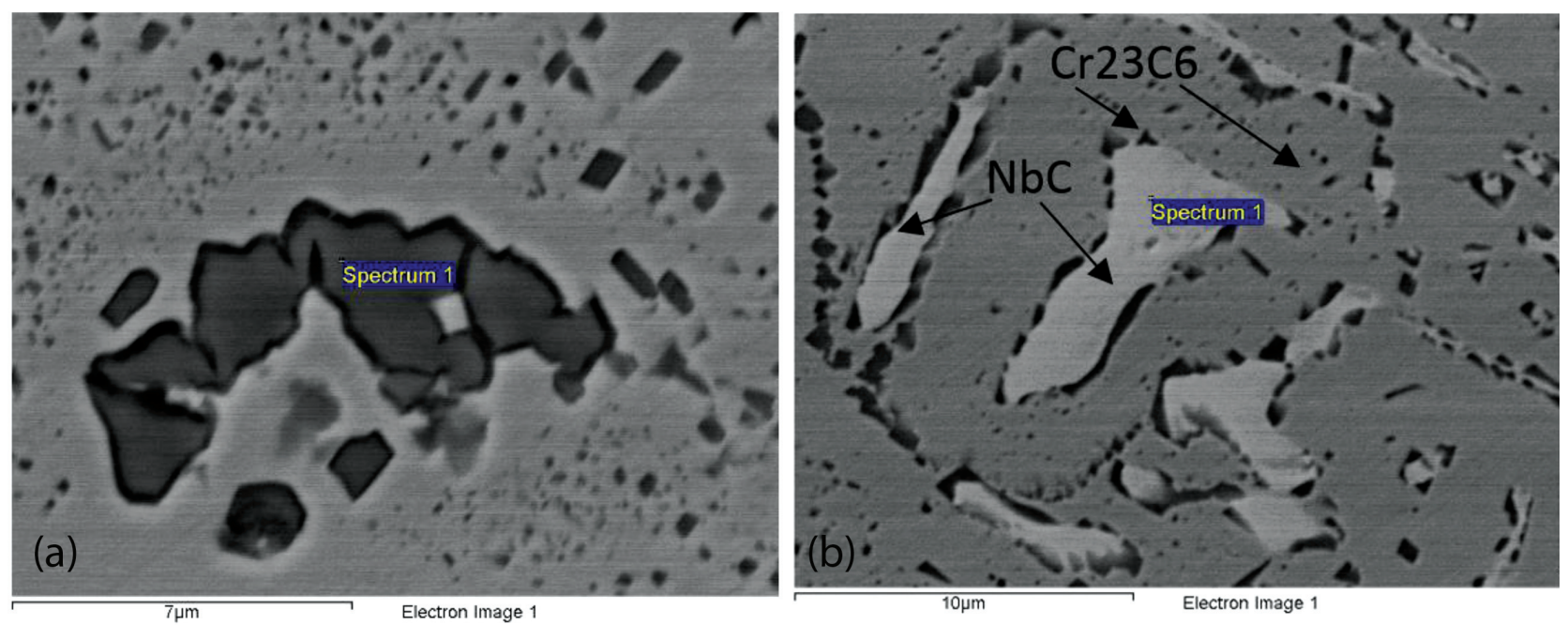

Figure 4: Details of the microstructure from Figure 3, with the locations of the quantitative EDS analysis marked: a) $\mathrm{Cr} 23 \mathrm{C} 6$ and b) $\mathrm{NbC}$

Table 6: Quantitative EDS analysis of the microstructure at the locations marked in Figure 4

\begin{tabular}{|c|c|c|c|c|c|c|c|c|}
\hline \multirow{2}{*}{$\begin{array}{c}\text { Spectrum/ } \\
\text { Figure }\end{array}$} & \multicolumn{7}{|c|}{ Amounts of elements (\%) } & \multirow{2}{*}{ Phase } \\
\hline & $\mathrm{C}$ & $\mathrm{O}$ & $\mathrm{Si}$ & $\mathrm{Cr}$ & $\mathrm{Ni}$ & $\mathrm{Fe}$ & $\mathrm{Nb}$ & $\mathrm{Cr} 23 \mathrm{C} 6$ \\
\hline $1 / \mathrm{a})$ & 7.48 & 26.19 & 1.34 & 32.07 & 6.75 & 23.67 & $\mathrm{NbC}$ \\
\hline $1 / \mathrm{b})$ & 19.16 & & & & & & 80.84 & $\mathrm{NbC}$ \\
\hline
\end{tabular}




\section{CONCLUSIONS}

This research was focused on the quality of the precipitation annealing of heat-resistant cast steel by carrying out a designed experiment. We used the Taguchi method to determine the effect of heat-treatment parameters on the mechanical properties. We examined the importance of controllable factors using the $S / N$ ratio approach. An analysis of the $S / N$ value was carried out using the mean values of the hardness. The results can be summarized as follows:

The research confirmed that the microstructure plays the key role in the achievement of certain properties, as well as the fact that it is susceptible to change during exploitation or under the influence of external factors, primarily the temperature; hence, the examination of the microstructure is of utmost importance. It is particularly important to study the carbide phase, which, with an austenitic basis, completes the microstructure. This study sheds light on its influence and, in some segments, it is in full agreement with the studies conducted on these phenomena and cited in the reference list.

In the process of precipitation annealing, significant transformations of the carbide phase take place in the microstructure, changing its morphology, distribution, size and composition. The breaking of the primarily separated, coarse carbide film along the boundaries of austenitic grains, redistribution in the array and special separation of fine dispersed carbides in the array, which are the carriers of all major properties, are the effects achieved in the microstructure during precipitating annealing,

The application of the designed experiment in our research confirmed that the Taguchi method is a conventional tool that differs from traditional applications. Especially in our case, it showed that the mechanical properties improved during the precipitation-annealing process.

\section{Acknowledgment}

This paper was created based on the knowledge and practical experience of both authors in the area of the above-presented topic without any specific grant from funding agencies in the public, commercial or non-profit sectors. No benefits in any form have been received, or will be received, from any commercial party related directly or indirectly to the subject of this paper.

\section{REFERENCES}

${ }^{1}$ M. Madić, Mathematical modeling and optimization of laser cutting process using artificial intelligence methods, $\mathrm{PhD}$ Thesis, Faculty of Mechanical Engineering, Niš 2013

${ }^{2}$ R. K. Roy, A Primer on the Taguchi Method, $2^{\text {nd }}$ ed., Society of Manufacturing Engineers, Michigan 2010, 304

${ }^{3}$ K. Hinkelmann, O. Kempthorne, Design and Analysis of Experiments, Vol. 2: Advanced Experimental Design, John Wiley \& Sons, Inc., New Jersey 2005, 816

${ }^{4}$ G. Taguchi, S. Chowdhury, Y. Wu, Taguchi's Quality Engineering Handbook, Vol. 2: Advanced Experimental Design, John Wiley \& Sons, Inc., New Jersey 2005, 1662

${ }^{5}$ P. D. Funkenbusch, Practical Guide to Designed Experiments: A Unified Modular Approach, CRC Press Taylor \& Francis Group, New York 2005, 224

${ }^{6}$ M. Topalušić, Six sigma methodology and test planning, MSc Thesis, Faculty of Mechanical Engineering and Naval Architecture, Zagreb 2014

${ }^{7}$ P. Shailesh, B. Praveen Kumar, S. Sundarrajan, M. Komariahia, Experimental investigation on centrifugal casting of 5500 alloy: A Taguchi approach, Scientific Research and Essays, 7 (2012), 3797-3808, doi:10.5897/SRE12.075

${ }^{8}$ M. Jurković, Mathematical modelling engineering of process and systems, Univerzity of Bihać, Bihać 1999, 402

${ }^{9}$ S. Butković, E. Šarić, M. Mehmedović, Microstructural changes during heat treatment of sintered austenitic nickel-free stainless steel, Annals of Faculty of Engineering Hunedoara, 16 (2018), 145-148

${ }^{10} Đ$. Dorđe, Physical metallurgy: physics of strength and plasticity 1, Faculty of Metallurgy, Beograd 1990, 401

${ }^{11}$ A. Delić, Researching the relations between microstructure and the properties of the heat resisting austenitic steel HK30 modified by niobium in order to improve the properties at elevated temperatures, PhD Thesis, Faculty of Metallurgy and Technology, Zenica 2018

${ }^{12}$ D. H. Stamatis, Quality Assurance: Applying Methodologies for Launching New Products, Services, and Customer Satisfaction, CRC Press Taylor \& Francis Group, New York 2015, 652

${ }^{13}$ A. Vagaska, P. Michal, M. Gombar, E. Fechova, J. Kmec, Simulation of technological process by usage neural networks and factorial design of experiments, MM Science Journal, (2016) 3, 999-1003, doi:10.17973/MMSJ.2016_09_201662

${ }^{14}$ J. A. Eguren, A. Esnaola, G. Unzueta, Modelling of an Additive 3D-Printing Process Based on Design of Experiments Methodology, Quality Innovation Prosperity, 24 (2020) 1, doi:10.12776/QIP. V24I1.1435

${ }^{15}$ K. Zgodavova, P. Bober, V. Majstorovic, K. Monkova, G. Santos, D. Juhaszova, Innovative Methods for Small Mixed Batches Production System Improvement: The Case of a Bakery Machine Manufacture, Sustainability, 12 (2020) 15, 6266, doi:10.3390/su12156266 